\title{
CONTABILIDADE TRIBUTÁRIA: PERCEPÇÃO DA IMPORTANCIA DO CONHECIMENTO DA DISCIPLINA POR DISCENTES DE UMA INSTITUIÇÃO DE ENSINO SUPERIOR DE TANGARÁ DA SERRA - MT.
}

\author{
Marli Anatália da Silva ${ }^{1}$ \\ Márcio Íris de Morais ${ }^{2}$
}

\section{RESUMO}

O objeto deste estudo é demonstrar a importância atribuída ao conhecimento da disciplina de contabilidade tributária por estudantes de graduação em Ciências Contábeis de Tangará da Serra - MT. Partindo do pressuposto da relevância da contabilidade tributária, na formação do profissional de contabilidade, evidenciaria então, ao futuro profissional da contabilidade, maior habilidade no tratamento tributário. O Objetivo foi demonstrar a importância da disciplina de contabilidade tributária determinada por estudantes de uma instituição de ensino superior (IES) do curso de ciências contábeis de Tangará da Serra - MT. Para coleta de evidências, utilizou-se do método de estudo de campo, processo de amostragem não probabilística e, aplicação de questionário com acadêmicos do oitavo semestre destaIES.Com um total de 28 respostas, as análises indicaram que os alunos acreditam que o conhecimento contábil tributário é fornecido de forma suficiente na IES. Também, oconteúdo programático e as matérias que abordam o tema tributário não são tão eficazes para garantir-lhes uma vaga no mercado de trabalho, aumentando assim a necessidade de maior aprofundamento da disciplina conforme conteúdo aplicado pela Universidade.

Palavras-chave: Contabilidade Tributária, Ensino Superior, Discentes.

\begin{abstract}
The object of this study is to demonstrate the importance attached to knowledge of the discipline of tax accounting for undergraduates in accounting of Tangara da Serra - MT. Assuming the relevance of tax accounting, training of accounting professional, then evinced, the future of professional accounting, greater skill in tax treatment. The goal was to demonstrate the importance of the discipline of tax accounting determined by students of a higher education institution (HEI) undergraduate accounting sciences of Tangara da Serra MT. For evidence collection, we used the method of field study, non-probability sampling process and a questionnaire for the eighth semester of this academic IES. With a total of 28 responses, the analysis indicated that students believe that the tax accounting knowledge is provided sufficiently in IES. The curriculum and materials that address the tax issue are not as effective in ensuring them a place in the labor market, thus increasing the need for further development of the discipline in applied research by the University.
\end{abstract}

Keywords: tributary accounting, Higher Education, Students.

\footnotetext{
${ }^{1}$ Acadêmica do curso Ciências Contábeis, da Universidade do Estado de Mato Grosso Campus Universitário de Tangará da Serra - UNEMAT, marlianatalia@yahoo.com.br.

${ }^{2}$ Orientador Professor do curso de Ciências Contábeis da Universidade do Estado de Mato

Grosso(UNEMAT),"Campus" Universitário de Tangará da Serra,Mestre em Contabilidade pela Universidade do Vale do Rio dos Sinos (UNISINOS), marciomorais@ unemat.br. 


\section{INTRODUÇÃO}

"As constantes transformações no mundo corporativo, no cenário globalizado, exigese do profissional de ciências contábeis uma formação adequada, de modo que sua atuação possa corresponder às expectativas do mercado e da sociedade"(Mendes et al, 2011, p. 2). A economia mundial e o ônus fiscal da carga tributária das empresas requerem do profissional contábil, práticas de gerenciamento eficazes e constantes para preservar a continuidade do empreendimento. Para se destacar no ramo contábil, o profissional precisa buscar e estar atento as mudanças da legislação, e um diferencial para se destacar é a forma legal de reduzir o pagamento de tributos (Nazário et al, 2008).

Com a evolução do ambiente econômico e social no qual o contador atua, Faria e Nogueira (2007), destacam a importância do profissional contábil em solucionar problemas, interpretar relatórios gerenciais e desenvolver o aspecto estrategista, pois é um grande auxiliador na tomada de decisões dentro das organizações, e o profissional deve estar preparado para essas mudanças.

Para Fabretti (2005), a contabilidade é a ciência que estuda, registra e controla o patrimônio e as mutações que nele operam os atos e fatos administrativos, demonstrando no final de cada exercício social o resultado obtido e a situação econômico-financeira da entidade. Portanto, para Araújo e Assaf (2004, p.14),“a contabilidade tem como maior objetivo gerar informações para gestores, diretores e outros usuários em relação à vida econômico-financeira da empresa. Por isso o profissional contábil tem grande valia nas organizações.” Araújo e Assaf (2004), afirma que, o profissional contábil está extremamente relacionado com o processo empresarial.

Conforme estudos realizados no Brasil em 2013, pelo Instituto Brasileiro de Planejamento Tributário, onde a carga tributária brasileira atingiu 37,65 \%, do Produto Interno Bruto (PIB), conjunto de bens e serviços produzidos no país, onde as receitas extraordinárias, que turbinaram tanto a arrecadação federal quanto a dos Estados. Nazário et al (2008, p. 65), questiona com isso a capacitação dos alunos com o conhecimento adquirido nas instituições de ensino superior para atuarem conforme as exigências do mercado.

Para Fabretti (2005, p.29) "contabilidade tributária é o ramo da contabilidade que tem por objetivo aplicar na prática conceitos, princípios e normas básicas da contabilidade e da legislação tributária, de forma simultânea e adequada". 
Nesse cenário, a fim de demonstrar a percepção da importância da contabilidade tributária para a formação do futuro profissional contábil, faz-se o seguinte questionamento: Qual importância do conhecimento da disciplina de contabilidade tributária atribuída por discentes do curso de Ciências Contábeis de uma instituição de ensino superior de Tangará da Serra - MT?

Para responder questões diante da relevância da contabilidade tributária, na formação do profissional de contabilidade, quanto ao processo decisório das empresas, o presente trabalho tem por objetivo demonstrar a importância da disciplina de contabilidade tributária atribuída por estudantes dos cursos de Ciências Contábeis de uma IES de Tangará da Serra MT. Para atingir o objetivo principal, utilizou-se dos seguintes objetivos específicos: a) Identificar a importância do conhecimento do conteúdo da disciplina de contabilidade tributária indicada por discentes do curso de ciências contábeis de Tangará da Serra - MT; b) Analisar os percentuais dos índices de importância que o estudante de graduação atribui aos assuntos tributários.

Esta pesquisa foi desenvolvida semelhante ao estudo realizado por Nazário et al (2008), em Brasília, no ano de 2008, em cinco IES que tinham na grade curricular a disciplina de Contabilidade Tributária, sendo uma federal e quatro particulares.

A estrutura deste trabalho está dividida em quatro partes com a finalidade de atingir o objetivo proposto. Após a introdução, a segunda parte versa sobrea contabilidade e o ensino contábil tributário, destacando aspectos de interesse e satisfação dos alunos em relação aos conteúdos estudados e os principais aspectos tributários assim como, o planejamento tributário no Brasil. Em seguida, apresenta-se a pesquisa realizada na IES de Tangará da Serra - MT. Na quarta parte, abordam-se as considerações finais.

\section{REFERENCIAL TEÓRICO}

\subsection{História e o Ensino da Contabilidade}

A Contabilidade existe desde a antiguidade, uma vez que desde o século IV a. C.,os homens controlavam seus bens e animais, através de marcas em arvores e até mesmo através de pedras, representando a quantidade de bens que possuíam, podendo controlar e conferir seus bens em termos de crescimento, perdas etc. Esta etapa da contabilidade foi denominada de fase empírica da Contabilidade (IUDÍCIBUS; MARION, 2007). 
Quando ainda não existia a moeda, praticava-se a troca de bens e mercadorias e, assim Iudícidus (2000) cita que, a prática da contabilidade surgiu com a necessidade do homem primitivo, contar e controlar seus rebanhos, suas ânforas de bebidas, onde os comerciantes já começavam anotar suas obrigações, os direitos e os bens perante terceiros. Para o autor, porém o homem progrediu e a contabilidade, que foi necessária para a evolução do processo da humanidade, também acompanhou essa evolução.

Entretanto, a preocupação com as propriedades e a riqueza é uma constante no homem da antiguidade (Como hoje também o é), ele teve de ir aperfeiçoando seu instrumento de avalição da situação patrimonial à medida que as atividades foram-se desenvolvendo em dimensão de complexidade [...]. (IUDÍCIBUS, 2004,p.31).

Em termos de registro histórico, é importante destacar Frei Luca Pacioli um grande matemático do século XV, que escreveu várias obras, dentre elas a obra Summa de Arithmetica, Geometrica, Proportioni et Proportionalita um tratado matemático que incluía uma seção denominada Tratactus de Computis et Scripturis publicada em 1494, cuja obra descreve em um de seus capítulos um método utilizado pelos mercadores de Veneza no controle de suas operações, que posteriormente foi denominado de método das partidas dobradas ou método de Veneza. (CREPALDI, 1999).

Entretanto, Iudícibus, Martins e Carvalho, (2005, p. 09), afirmam que "não se sabe muito bem quem inventou o método das partidas dobradas, mas não há dúvidas de que Pacioli lhe emprestou um significado eminentemente matemático”.

[...] A contabilidade teve seu florescer, como disciplina adulta e completa, nas cidades italianas de Veneza, Gênova, Florença, Pisa e outras. Estas cidades e outras da Europa fervilhavam de atividade mercantil, econômica e cultural, momento a partir do século XIII até o início do século XVII. Representaram o que de mais avançado poderia existir, na época, em termos de empreendimentos comerciais e industriais incipientes. Foi nesse período, obviamente, que Pacioli escreveu seu famoso Tractatus de coputis et scripturi, provavelmente o primeiro a dar uma exposição completa e com muitos detalhes, ainda hoje atual, da Contabilidade. (IUDÍCIBUS, 2009, p. 16).

Lima (2006, apud Agostini; Carvalho, 2011, p. 4) defende a contabilidade em quatro etapas da sua evolução, conforme o quadro abaixo: 
Quadro 1 - Etapas da evolução da contabilidade

\begin{tabular}{|c|l|}
\hline \multicolumn{1}{|c|}{ Período } & \multicolumn{1}{c|}{ Características } \\
\hline $\begin{array}{c}\text { Contabilidade do } \\
\text { Mundo Antigo }\end{array}$ & $\begin{array}{l}\text { Período que se inicia com a civilização do homem e vai até 1202 da Era Cristã, } \\
\text { quando apareceu o Líber Abaci, da autoria Leonardo Fibonaci, o Pisano. }\end{array}$ \\
\hline $\begin{array}{c}\text { Contabilidade do } \\
\text { Mundo Medieval }\end{array}$ & $\begin{array}{l}\text { Período que vai de 1202 da Era Cristã até 1494, quando apareceu o Tratactus de } \\
\text { Computis et Seriptures (Contabilidade por Partidas Dobradas) de Frei Luca } \\
\text { Pacioli, publicado em 1494; enfatizando que à teoria contábil do débito e do } \\
\text { crédito corresponde à teoria dos números positivos e negativos, obra que contribui } \\
\text { para inserir a contabilidade entre os ramos do conhecimento humano. }\end{array}$ \\
\hline Contabilidade do & $\begin{array}{l}\text { Período que vai de 1494 até 1840, com o aparecimento da Obra "La Contabilità } \\
\text { Applicatta Alle Amninistrazioni Private e Pubbliche", da autora de Francesco } \\
\text { Villa, premiada pelo governo da Áustria. Obra marcante na história da } \\
\text { Contabilidade. }\end{array}$ \\
\hline Contabilidade do & Período que se inicia em 1840 e continua até os dias de hoje. \\
Mundo Científico & \\
\hline
\end{tabular}

Fonte: (Lima 2006, p. 01)

A definição de Contabilidade, apontado por Fabretti (2005) é a ciência que estuda, registra e controla o patrimônio e as mutações que nele operam os atos e fatos administrativos, demonstrando no final de cada exercício social o resultado obtido e a situação econômico-financeira da entidade.

No Brasil, a contabilidade foi fortemente influenciada pela escola italiana, e evoluiu através da legislação fiscal, pois, segundo Iudícibus (2000), devido à inoperância das associações dos contadores o governo teve que tomar a iniciativa. Em 1902, Iudícibus (2009) cita, que, para dar impulso ao ensino contábil, foi criada a Escola de Comércio Álvares Penteado que se especializava em contabilidade. Logo, em 1946, foi criada a Faculdade de Ciências Econômicas e Administrativas da USP, instalando, também, o curso de Ciências Contábeis e Atuarias. Nessa faculdade foi que Francisco D’Auria, Frederico Herrmann Júnior e outros professores conceituados, puderam realizar trabalhos científicos de tamanho valor e dando base para o surgimento de outros novos talentos da contabilidade.

No ano de 1946 foi criado o CFC (Conselho Federal de Contabilidade), que define as atribuições do Contador e do Guarda-livros e dá outras providências, com Decreto de Lei no 9.295, de 27 de maio de 1946, no Art. $1^{\circ}$ ficam criados o Conselho Federal de Contabilidade e os Conselhos Regionais de Contabilidade, de acordo com o que preceitua o presente Decreto Lei.

A criação do Conselho Federal de Contabilidade, atribuído para organizar o seu regimento interno, aprovar os Regimentos Internos organizados pelos Conselhos Estaduais, tomar conhecimento de quaisquer dúvidas suscitadas nos Conselhos Regionais e dirimi-las, decidir em última instância, recursos de penalidade imposta pelos Conselhos Regionais, publicar o relatório anual de seus trabalhos, em que deverá figurar a relação de todos os profissionais registrados (MOURA, 2003, p. 8). 
Portanto, para os Contabilistas e os Escritórios de Contabilidade exercerem suas atividades profissionais, deverá ser registrado no CRC.

\subsection{Conceito de Contabilidade Tributária.}

De acordo com Fabretti (2006), contabilidade tributária é a área de aplicação das ciências contábeis que tem como objetivo apurar com exatidão o resultado econômico do exercício social, para conciliar a geração de tributos de uma determinada entidade. Assim para atingir esse objetivo, através da escrituração contábil, é preciso estudar, registrar e controlar os fatos administrativos que produzem mutações patrimoniais e obtendo resultado econômico positivo ou negativo (lucro ou prejuízo).Segundo Fabretti (2005, p.29) "é ramo da contabilidade que tem por objetivo aplicar na prática conceitos, princípios e normas básicas da contabilidade e da legislação tributária, de forma simultânea e adequada”. Ainda assim, Fabretti complementa:

Como ramo da contabilidade, deve demonstrar a situação do patrimônio e o resultado do exercício, de forma clara e precisa, rigorosamente de acordo com conceitos, princípios e normas básicas de contabilidade. O resultado apurado dever ser economicamente certo. (FABRETTI, 2006, p. 29).

Dentro do seguimento de contabilidade tributária, a definição de planejamento tributário, é o "estudo feito preventivamente, ou seja, antes da realização do fato administrativo, pesquisando-se seus efeitos jurídicos e econômicos e as alternativas legais menos onerosas." Fabretti (2006, p. 32).

\footnotetext{
Corresponde ao conjunto de atuações e procedimentos operacionais de uma empresa (especialmente os contábeis) que levaria a uma redução legal do ônus tributário empresarial, recolhendo exatamente o montante devido que foi gerado em suas operações, fazendo com que venha a obter um patamar superior de rentabilidade e competitividade, (OLIVEIRA, 2005, p. 167).
}

Neste contexto, Nazário et al (2008) define planejamento tributário como qualquer ato para redução da carga tributária. Desta forma, foram criadas as figuras da elisão, evasão e elusão tributária. De acordo com Oliveira (2005), o conceito de evasão corresponde ao agente (contribuinte) que, por meios ilícitos, visa a acabar, diminuir ou retardar o recolhimento de um tributo já devido pela ocorrência do fato gerador. Enquanto na elisão, o contribuinte 
licitamente visa a evitar, minimizar ou adiar a ocorrência do fato gerador antes que este fato ocorra, evitando assim a origem da obrigação tributária. Oliveira (2005, p.169) destaca ainda que, "na elusão, o contribuinte assume o risco pelo resultado, visando a uma tributação menos onerosa, conforme o uso de meios atípicos - seja para evitar a ocorrência do fato gerador, seja para pô-lo em subsunção com uma norma menos dispendiosa".

Os dois termos não são causais nem destituídos de sentido semântico, dado que a evasão fiscal significa a fuga da obrigação tributária existente segundo a lei (daí a ilicitude), ao passo que a elisão quer dizer elidir legalmente a ocorrência da obrigação tributária (daí a licitude). (OLIVEIRA, 2005, p. 168).

É oportuno, de início, transcrever o conceito dado pelo Código Tributário Nacional à Legislação Tributária, conforme art. 96 da Lei nº 5.172/66, de 25 de outubro de 1996:

Art. 96: A expressão legislação tributária compreende de leis, os tratados e as convenções internacionais, os decretos e as normas complementares que versem, no todo ou em parte, sobre tributos e relações jurídicas a eles pertinentes.

Conforme a CF/88, Art. 145, o Sistema Constitucional Tributário é um conjunto de disposições relacionadas na constituição de um Estado, destinadas a regulamentar a atividade tributária, tais disposições determinam os instrumentos da tributação que são: impostos, taxas e contribuição de melhoria.

O Código Tributário Nacional prescreve em seu Art. $3^{\circ}$, a seguinte definição: Tributo é toda prestação pecuniária compulsória, em moeda ou cujo valor nela se possa exprimir, que não constitua sanção de ato ilícito, instituída em lei e cobrada mediante atividade administrativa plenamente vinculada.

De acordo com a CF, compreendem os impostos, as taxas e a contribuição de melhoria, conforme previsto em seu Artigo 145.

\footnotetext{
"Art. 145. A União, os Estados, o Distrito Federal e os Municípios, poderão instituir os seguintes tributos:

I - Impostos;

II - Taxas, em razão do exercício do poder de polícia ou pela utilização, efetiva ou potencial, de serviços públicos específicos e divisíveis, prestados ao contribuinte ou postos a sua disposição;

III - Contribuição de Melhoria, decorrente de obras públicas.

$\S$ 1. ${ }^{\circ}$ - Sempre que possível, os impostos terão caráter pessoal e serão graduados segundo a capacidade econômica do contribuinte, facultando à administração tributária, especialmente para conferir efetividade a esses objetivos, identificar,
} 
respeitados os direitos individuais e nos termos da lei, o patrimônio, os rendimentos e as atividades econômicas do contribuinte.

$\S 2 .^{\circ}-$ As taxas não poderão ter base de cálculo própria de impostos. "

Definições de Imposto, Taxa e Contribuição de Melhoria, segundo o Código Tributário Nacional:

Art. 16. Imposto é o tributo cuja obrigação tem por fato gerador uma situação independente de qualquer atividade estatal específica, relativa ao contribuinte.

Art. 77. As taxas cobradas pela União, pelos Estados, pelo Distrito Federal ou pelos Municípios, no âmbito de suas respectivas atribuições, têm como fato gerador o exercício regular do poder de polícia, ou a utilização, efetiva ou potencial, de serviço público específico e divisível, prestado ao contribuinte ou posto à sua disposição.

Art. 81. A contribuição de melhoria cobrada pela União, pelos Estados, pelo Distrito Federal ou pelos Municípios, no âmbito de suas respectivas atribuições, é instituída para fazer face ao custo de obras públicas de que decorra valorização imobiliária, tendo como limite total a despesa realizada e como limite individual o acréscimo de valor que da obra resultar para cada imóvel beneficiado.

\subsection{Diretrizes Curriculares Referentes à Contabilidade Tributária}

Oliveira et al (2007), embasados na diretriz curricular CNE $n^{\circ} 10 / 2004$, publicada pelo Ministério da Educação e Cultura, através do Conselho Nacional de Educação, cita as seguintes competências e habilidades que a disciplina contabilidade tributária deve proporcionar ao aluno:

a) agregar conhecimentos que possibilitem aos acadêmicos interpretar e empregar corretamente a legislação tributária em vigor e seus reflexos nos livros contábeis;

b) proporcionar conhecimentos que visem ao desenvolvimento e aperfeiçoamento da cultura tributária "federal, estadual e municipal" incentivando o poder de decidir qual o melhor "caminho tributário" a ser adotado pelas empresas quando enfrentarem o mercado de trabalho atual;

c) usar adequadamente a linguagem contábil, sob a abordagem da teoria da comunicação (semiótica);

d) usar raciocínio lógico e crítico-analítico para a solução de problemas vinculados aos custos tributários; 
e) usar relatórios que contribuam para o desempenho eficiente e eficaz de seus usuários;

f) articular, motivar e liderar equipes multidisciplinares para a captação de dados, geração e disseminação de informações contábeis tributárias;

g) desenvolver, analisar e implantar sistemas de informações tributário-contábil e de controle gerencial; e

h) exercer com ética as atribuições e prerrogativas que lhes são prescritas por de legislação específica.

No âmbito educacional, a motivação pode ser entendida como um processo que conduz os indivíduos à realização de atividades e tarefas, ela é evidenciada a partir de um comportamento, o que a torna observável (RIBAS, 2008). A autora conceitua a motivação como:

[...] um impulso, força, desejo ou estímulo, que varia de indivíduo para indivíduo e que o conduz à ação, fazendo-o se esforçar e persistir numa tarefa. Ela é dependente de fatores pessoais (crenças, autoconceitos, objetivos, expectativas), metodológicos (postura e forma de trabalhar do professor) e físicos, materiais e administrativos da escola (normas e recursos oferecidos) (RIBAS, 2008 p.53).

Para Nazário et al (2008, apud Hesketh, 1981, p. 109), motivação é definida como “o resultado da interação entre o indivíduo e a situação e a vontade de empregar altos níveis de esforço em direção a metas, condicionada pela capacidade do esforço de satisfazer alguma necessidade do indivíduo". Para o autor, quando alguém está motivado, o esforço é direcionado e coerente com a meta a ser atingida. É um processo de satisfação de necessidades, estado interno do indivíduo que faz certos resultados parecerem atraentes.

Segundo Nazário et al (2008, apud Hesketh, 1981, p. 93),satisfação é definida por como a atitude geral do indivíduo com relação ao foco de sua ação. É o estado de contentamento do indivíduo conforme suas ações. "Interesse, em seu sentido abrangente, é a forma de manifestar um motivo para fazer ou deixar de fazer qualquer coisa. Já a palavra satisfação é justificada pelo porquê de estar motivado.” (NAZÁRIO et al, 2008, p.67).

\section{METODOLOGIA}

Segundo Prodanov e Freitas (2013, p. 192) "a metodologia é compreendida como uma disciplina que consiste em estudar, compreender e avaliar os vários métodos disponíveis para a realização de uma pesquisa acadêmica." De acordo com Oliveira (2001) a metodologia 
estuda os meios ou métodos de investigação do pensamento concreto e do pensamento verdadeiro, e procura estabelecer a diferença entre o que é verdadeiro e o que não é entre o que é real e o que é ficção. O tipo de delineamento utilizado para a primeira parte da pesquisa foi por meio de bibliografia especializada, ou seja, a investigação da literatura. A segunda parte da pesquisa é do tipo descritiva, realizada por meio de levantamento ou survey, com enfoque quantitativo.

A população constitui-se dos acadêmicos do $8^{\circ}$ semestre do ano 2014/1 e que cursaram a disciplina de contabilidade tributária no $7^{\circ}$ semestre, em 2013/2. Inicialmente com 34 acadêmicos matriculados, somente trinta finalizaram a disciplina, conforme lista do SAGU (Sistema Aberto de Gestão Unificada), fornecida pelo professor da disciplina.

Fundamentado na literatura pesquisada, foi realizado questionário composto por 16 perguntas. Os dados foram coletados através de uma survey, disponibilizado à população no período de 24/03/2014 a 26/03/2014, entre 20:00 e 22:00 horas, em sala de aula. Anexo ao questionário seguiu-se uma carta de apresentação onde se descrevia, resumidamente, a proposta da pesquisa.

\subsection{TRATAMENTO DOS DADOS}

Os dados obtidos foram armazenados em um banco de dados e, após, quantificados e submetidos a análises estatísticas. O tratamento dos dados foi realizado por meio da utilização do programa Microsoft Excel 2013®.

Os resultados foram tabulados e utilizou-se análise descritiva dos dados, através da construção de tabelas de frequência simples e apuração da média, quando aplicáveis, permitindo-se uma análise quantitativa dos dados por distribuição de frequências, que, para Sampieri (2010, p.416), "é um conjunto de pontuações ordenadas em suas respectivas categorias". Conforme o autor, ainda poderá ser apresentado para melhor visualização, através de histogramas e gráficos que melhor componham a visualização e interpretação dos resultados.

\subsection{ESTUDO EM UMA INSTITUIÇÃO DE ENSINO SUPERIOR DE TANGARÁ DA SERRA - MT.}


O questionário aplicado aos discentes foi composto por questões objetivas e separadas em três partes, contendo 16 perguntas de múltipla escolha. O objetivo da primeira parte é identificar o grau de satisfação do aluno em relação ao conteúdo vinculado à tributação. Em seguida, é objeto de estudo perceber o grau de interesse do aluno com relação à matéria ministrada na IES. Finalmente, a última parte do questionário objetiva apresentar o grau mínimo de conhecimento adquirido na matéria.

Foram também realizadas algumas conexões de respostas para um aprofundamento melhor do conteúdo pesquisado. Esta mensuração foi dada da seguinte forma: a) se o aluno tem interesse pela matéria, a sua satisfação com o conteúdo recebido na faculdade foi correspondida?; b) se o aluno se interessa pelo assunto e se sente satisfeito com o conhecimento adquirido ele consegue responder de forma correta às questões que envolvem conhecimento? e; c) quais as expectativas futuras dos alunos que têm interesse no assunto?

\section{DISCUSSÃO E ANÁLISE DOS RESULTADOS}

\subsection{Perfil da amostra}

A população de discentes dos cursos de graduação em Ciências Contábeis da IES pesquisada totalizou 30 e a quantidade total de questionários respondidos foi de 28 . Verificouse que o perfil dos graduandos, conforme tabela 1, da instituição.

Tabela 1 - Perfil da Amostra

Perfil da Amostra

\begin{tabular}{c|c|c|}
\hline $\begin{array}{l}\text { População: Quantidade total } \\
\text { de alunos }\end{array}$ & $\begin{array}{l}\text { Amostra: Quantidade de } \\
\text { questionários respondidos }\end{array}$ & $\begin{array}{l}\text { Representatividade } \\
\text { Amostra }\end{array}$ \\
\hline 30 & 28 & $93,34 \%$ \\
\hline
\end{tabular}

\subsection{Análise da satisfação quanto aos conhecimentos adquiridos}

Foi questionado aos alunos a percepção deles quanto ao conhecimento fiscal/tributário, adquirido no curso de graduação, conforme demonstrado no gráfico 1.

Gráfico 1 - Qual a percepção quanto ao conhecimento fiscal/tributário, adquirido na instituição. 


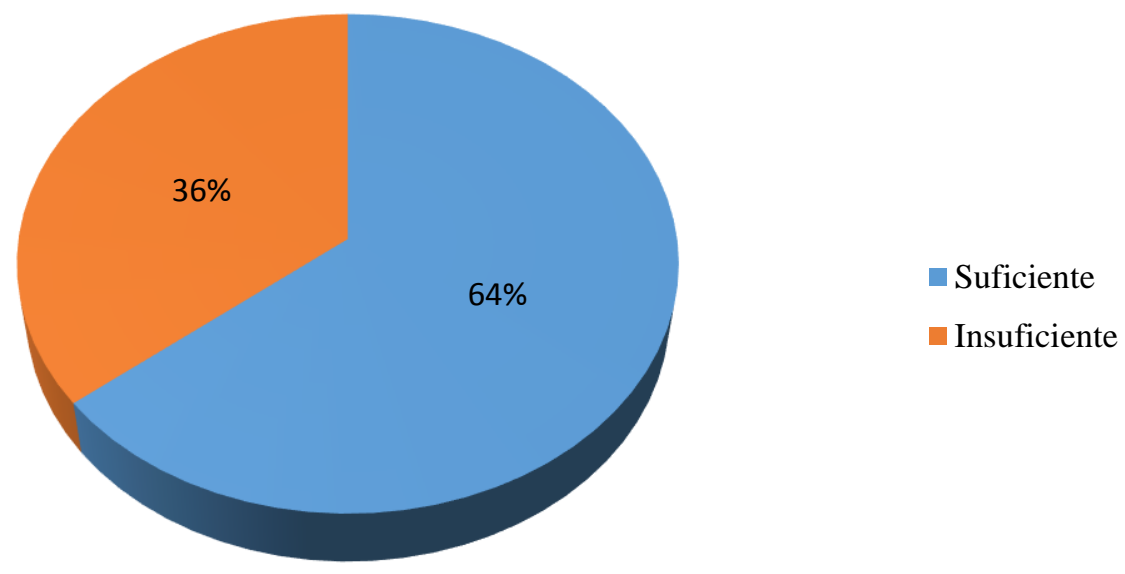

Fonte: dados da pesquisa

Dos 28 alunos entrevistados, 36\% acreditam que o conhecimento adquirido na Universidade foi insuficiente; $64 \%$ dos respondentes acreditam ser suficiente tal conhecimento. Entretanto em pesquisa semelhante desenvolvida por Nazário et al (2008), houve divergência nos resultados, pois naquele estudo, $62 \%$ do total, acreditavam que o conhecimento adquirido na Universidade era insuficiente; $30 \%$ dos respondentes acreditavam ser suficiente tal conhecimento. Na instituição analisada, a satisfação dos alunos foi superior a $50 \%$.

A questão 2 não pretendeu examinar a matéria, mas sim o conteúdo programático das disciplinas que estão vinculadas à contabilidade tributária, conforme demonstrado no gráfico 2:

\section{Gráfico 2 - Nível de satisfação com o conteúdo programático}

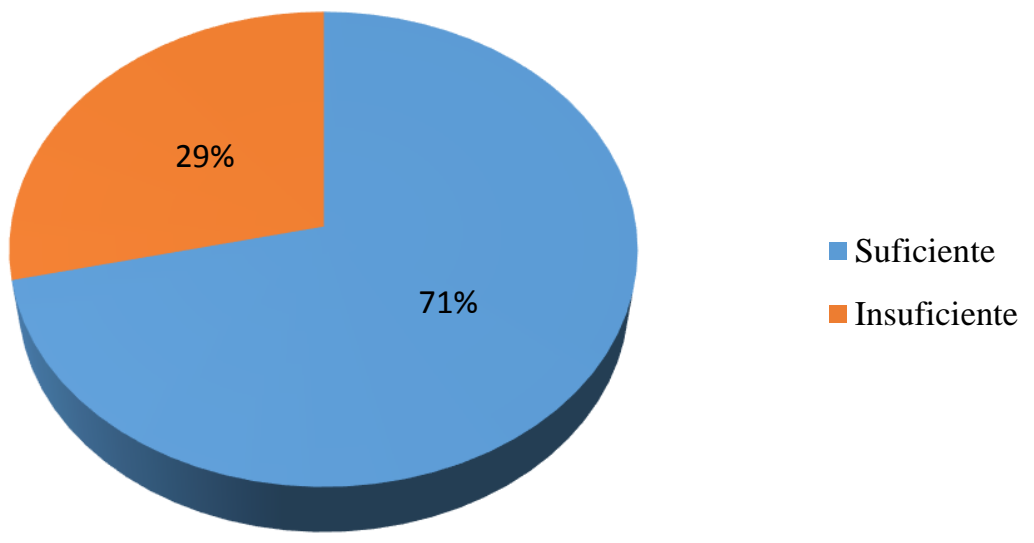

Fonte: dados da pesquisa

Conforme o gráfico 2, 71\% dos respondentes afirmaram que o conteúdo programático foi suficiente para seu conhecimento acadêmico e $29 \%$ estão insatisfeitas com o conteúdo 
programático vinculado ao fisco. Entretanto houve divergência nos resultados em pesquisa semelhante desenvolvida por Nazário et al (2008), pois naquele estudo, a maioria dos alunos, $60 \%$ dos respondentes está insatisfeita com o conteúdo programático vinculado ao físco e $30 \%$ dos respondentes acreditavam que o conteúdo vinculado a contabilidade tributária é suficiente para tal conhecimento.

A questão 3 é a que revela o maior grau de insatisfação dos pesquisados, conforme demonstra o gráfico 3. Nesta questão, foi questionado se os conhecimentos adquiridos nas IES seriam suficientes para que o aluno se sentisse capacitado para atuar no mercado de trabalho.

Gráfico 3 - Nível de satisfação em relação ao mercado de trabalho fiscal/tributário

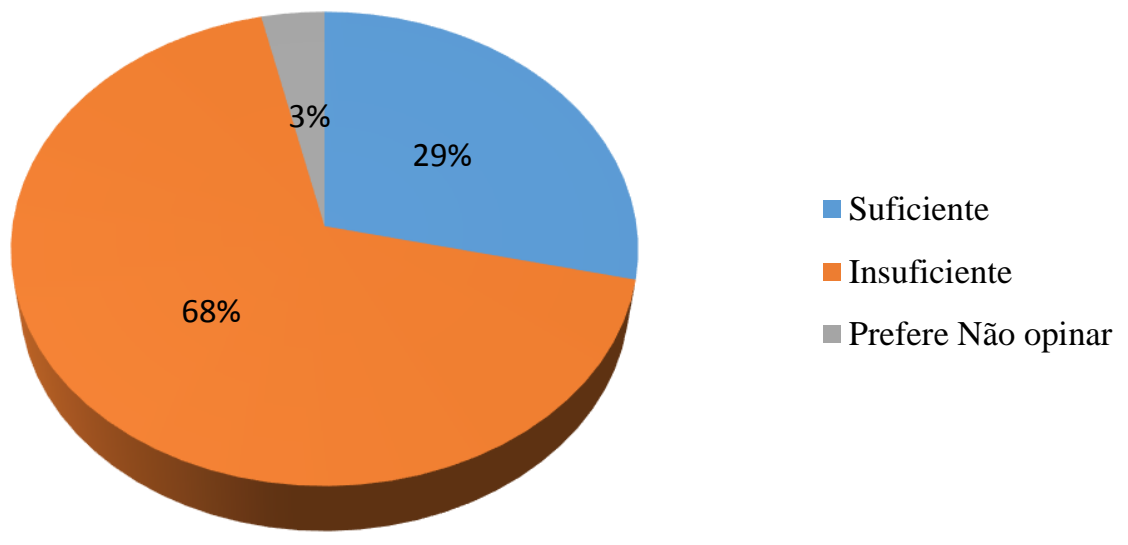

Fonte: dados da pesquisa

O gráfico 3, onde68\% dos entrevistados, acreditavam que o conhecimento adquirido na IES é insuficiente, na pesquisa semelhante desenvolvida por Nazário et al (2008) o resultado identificou que $74 \%$ dos entrevistados, também acreditavam que o conhecimento adquirido na IES é insuficiente para se sentir capacitado para atuar no mercado de trabalho.

\subsection{Análise do interesse pelo assunto tributário}

As questões pertinentes a essa parte do questionário objetivaram identificar de forma abrangente o interesse dos alunos como fatores que motivam e desmotivam, assim como as expectativas e interesse direto pelo assunto fiscal/tributário.

A pergunta 4, enfoca o interesse dos estudantes em relação ao conhecimento fiscal/tributário adquirido na faculdade para seu futuro como contabilista.

Gráfico 4 - Nível de interesse dos alunos em relação aos assuntos fiscais/tributários 


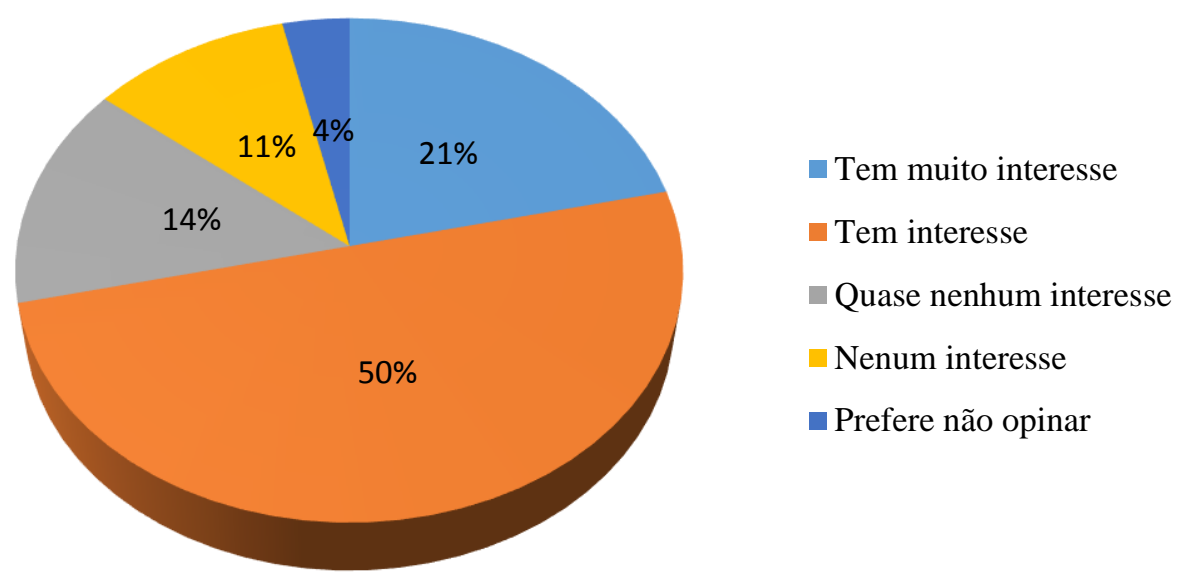

Fonte: dados da pesquisa

Conforme o gráfico 4 , onde $50 \%$ dos respondentes têm interesse e $21 \%$ têm muito interesse no assunto, nesta pergunta, os resultados quase se igualaram com pesquisa desenvolvida por Nazário et al (2008), onde 53\% têm interesse e 22\% têm muito interesse. Esta questão pode ser considerada importante para o estudo, porém, associada às outras questões que envolvem o interesse dos alunos, mostrou-se imprescindível para a análise dos resultados.

De acordo com o Gráfico 5, foi questionado aos alunos o que lhes faziam sentirem motivados com os assuntos tributários. Com $41 \%$ do total, em que a maioria dos alunos responderam, acreditaram que associar a teoria à prática é o principal motivo para motivação do estudo, $15 \%$ dos respondentes, acreditam que as minúcias da lei e $15 \%$ de captar os conhecimentos repassados pelo professor, também são fatores relevantes para a motivação para o estudo e $11 \%$ descreveram a própria capacidade de diversificar os conhecimentos contábeis. Na pesquisa desenvolvida por Nazário et al (2008), os resultados foram bem diferentes da pesquisa desenvolvida em Tangará da Serra, com 39\% do total, as minúcias da lei foi o item em que a maioria dos alunos respondeu como fator principal para motivação do estudo, 24\% descreveram a própria capacidade de diversificar os conhecimentos contábeis e $18 \%$ acreditaram que associar a teoria à prática

Gráfico 5 - Itens de motivação dos alunos em relação aos assuntos fiscais/tributários 


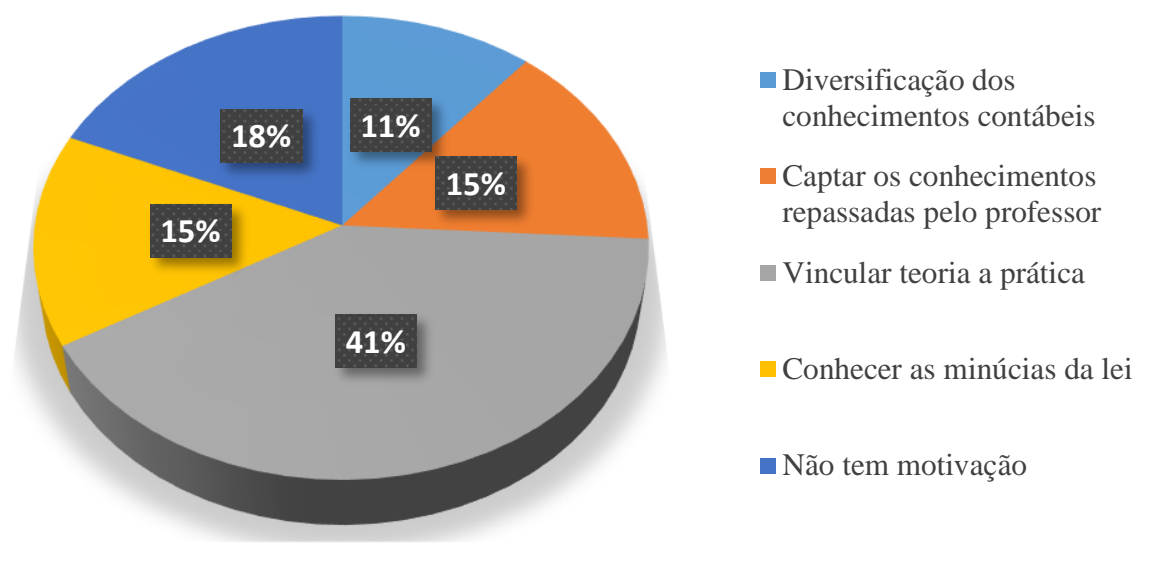

Fonte: dados da pesquisa

A questão 6, ao contrário da anterior, questionava o principal fator para que os alunos não se sentissem motivados com o assunto. $O$ resultado encontrado demonstra que $57 \%$ dos alunos apontam como principal fator para não se sentirem motivados, são as complexidades das leis, $14 \%$ dos respondentes não ficam desmotivados com os assuntos tributários, com o percentual de $11 \%$, os respondentes, acham que, o professor e outras áreas mais rentáveis da contabilidade são um fatores desmotivadores e 7\% acreditam que a Faculdade é um dos motivos por se sentirem desmotivados com as questões tributárias, pois esta não lhes prepara suficiente para o mercado de trabalho. O resultado encontrado por Nazário et al (2008), demonstrou que $43 \%$ dos alunos não têm motivos para se sentirem desmotivados com a matéria, enquanto $28 \%$ acreditam que o motivo de sua decepção com as questões tributárias é causado pela IES, pois esta não lhe prepara para o mercado de trabalhoe $13 \%$ dos respondentes acham que existem outras áreas na contabilidade que são mais rentáveis, resultados estes, que diferenciam dos resultados obtidos em Tangará da Serra.

\section{Gráfico 6 - Fatores para falta de motivação}

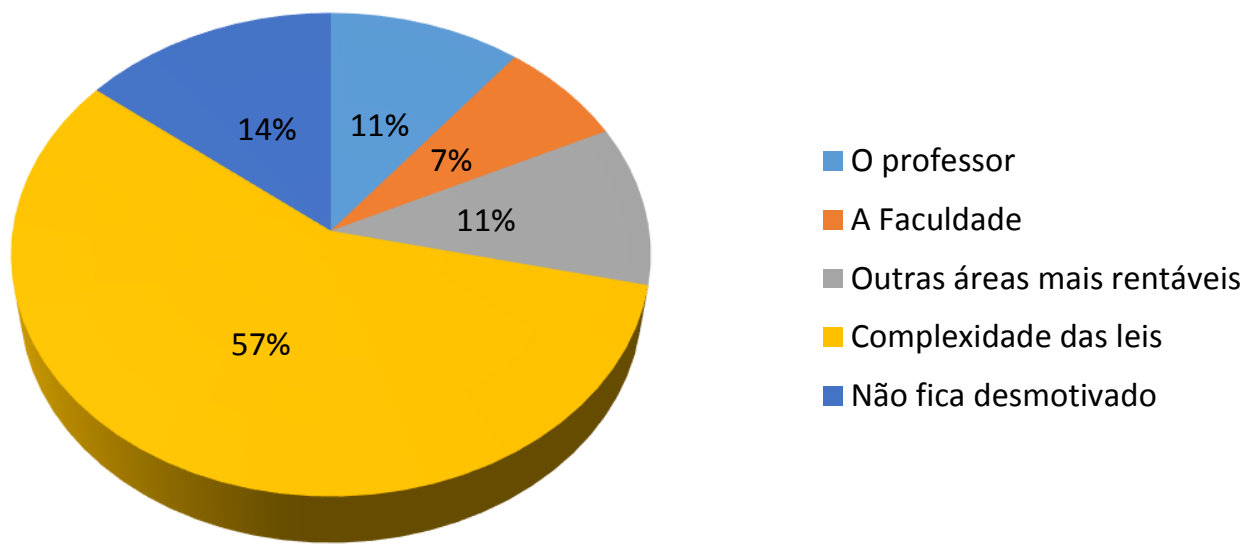

Fonte: dados da pesquisa 
A outra questão, conforme gráfico 7,perguntava ao graduando se ele já havia trabalhado na área de planejamento tributário, fora do ambiente acadêmico. Dos respondentes, $68 \%$ dos alunos afirmaram nunca terem trabalhado com planejamento tributário. E 18\% destacaram que trabalharam por pouco tempo e $14 \%$ trabalham na área. Verificou-se ainda que nenhum dos alunos trabalharam por muito tempo. Verifica-se aqui, em analogia às questões anteriores, que o interesse dos alunos por adquirir este conhecimento é fruto do que se fala sobre o tema e não de sua prática. Apenas 14\% dos pesquisados trabalham na área.

Gráfico 7 - Se já trabalhou na área de planejamento tributário, fora o ambiente de acadêmico

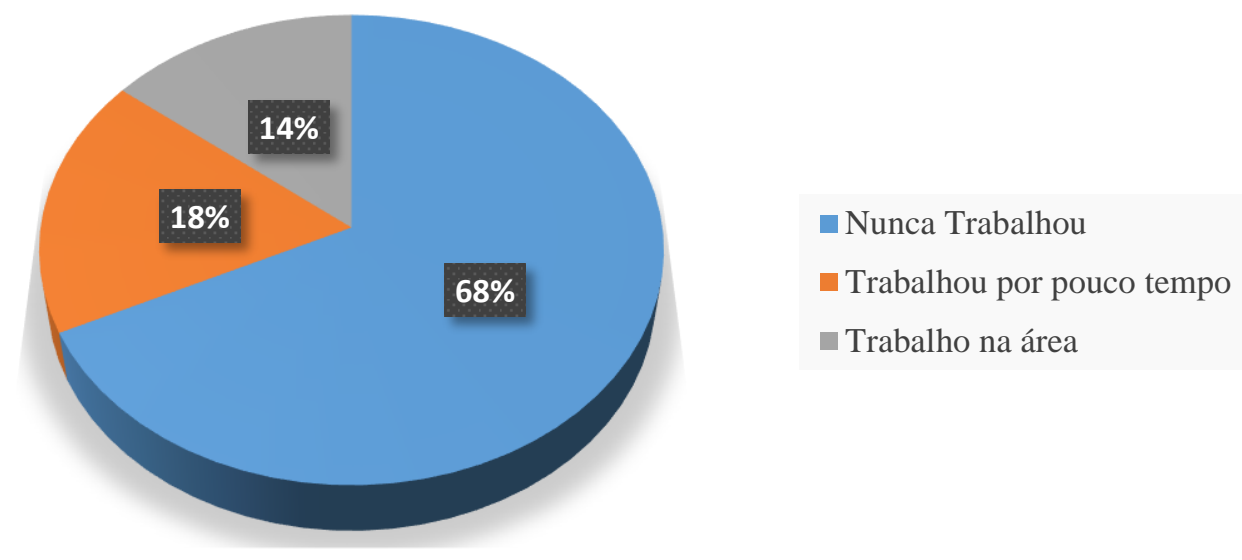

Fonte: dados da pesquisa

No gráfico 8, questionou-se, em seguida, o que o aluno faria no futuro com o conhecimento tributário adquirido. Dos respondentes,54\% usariam a contabilidade tributária com enfoque em concursos, existe uma indecisão para os alunos, sendo que $32 \%$ dos universitários não sabem o que fazer no futuro com os conhecimentos adquiridos e $7 \%$ irão se especializar na área e outros $7 \%$ manterá distância dos assuntos tributários.

\section{Gráfico 8 - Uso tributário no futuro}

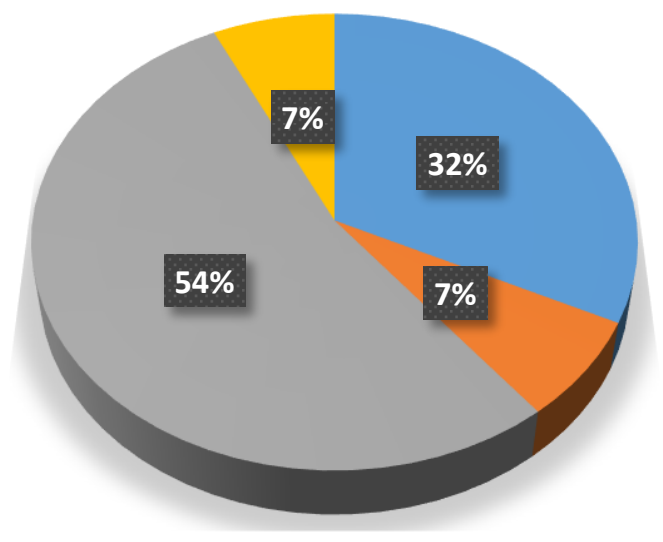

- Não sei ao certo o que fazer com conhecimentos adquiridos

- Manterei distância de assuntos tributários

Enfoque somente em concursos

- Farei especialização na área

Fonte: dados da pesquisa 
Nas questões que envolvem o interesse dos alunos, verificou-se a necessidade de um maior aprofundamento. A pesquisa neste ponto se voltou aos alunos que responderam à questão relativa a possuírem interesse ou muito interesse no assunto tributário. Conforme Gráfico 8.

\subsection{Análise do grau de fixação dos conhecimentos tributários}

Ao se analisar o grau de satisfação e o interesse dos universitários pesquisados, o estudo então procurou saber a capacidade de fixação do conteúdo repassado a estes. As questões envolvem conhecimentos mínimos em que os alunos devem ter, caso este realmente tenha interesse em atuar na área tributária. Neste momento, o aluno foi convidado a participar de uma simulação de uma prova para analista tributário. A primeira pergunta se referia ao que o aluno considerava como planejamento tributário.

Tabela 2 - Conhecimento sobre conceito de planejamento tributário Em minha opinião, planejamento tributário é:

a) diminuir impostos, não importa os métodos que sejam utilizados

Quantidade

$\%$

b) omitir informações irrelevantes para retardar a ocorrência da carga tributária

c) prever a incidência do fato gerador do imposto e trabalhar para que ele não ocorra, ocorra de forma mais amena ou postergar a sua ocorrência.

d) não sei

\begin{tabular}{|c|r|}
\hline 0 & $0 \%$ \\
\hline 0 & $0 \%$ \\
\hline 25 & $89 \%$ \\
\hline 03 & $11 \%$ \\
\hline $\mathbf{2 8}$ & $\mathbf{1 0 0 \%}$ \\
\hline
\end{tabular}

Total

28

Fonte: dados da pesquisa

Conforme os resultados demonstrados na Tabela 2, 89\% dos discentes conseguem definir o que é planejamento tributário, resultado esse, que quase se iguala a pesquisa aplicada por Nazário et al (2008), que obteve um resultado de 86,4\%.

Em outra questão, o aluno deveria ter conhecimento em qual empresa haveria a incidência do fato gerador do Imposto sobre a Circulação de Mercadorias e Serviços e Transporte Interestadual e de Intermunicipal e de Comunicação (ICMS) e os resultados são demonstrados na Tabela 3.

Tabela 3 - Fato gerador do ICMS

\begin{tabular}{lcc}
\hline Haverá a incidência do fato gerador do ICMS quando: & Quantidade & $\%$ \\
\hline a) a empresa gerar proventos de qualquer natureza & 09 & $33 \%$ \\
\hline b) a empresa prestar serviços contábeis e advocatícios & 02 & $8 \%$ \\
\hline c) a empresa sonegar informações ao fisco & 02 & $7 \%$ \\
\hline d) houver a circulação de mercadoria da matriz para a filial & 14 & $52 \%$ \\
\hline Total & $\mathbf{2 7}$ & $\mathbf{1 0 0 \%}$ \\
\hline
\end{tabular}

Fonte: dados da pesquisa 
O número de alunos que acertaram essa outra questão foi razoável, porém, com um percentual menor que o da anterior. Dos respondentes, 52\% dos alunos souberam responder corretamente a pergunta, em função que o fato gerador existe, mas a isenção por parte da SEFAZ - MT nesta operação, entretanto houve alto índice que refere-se a fatos vinculados a folha de pagamento das empresas, o que demonstrou uma margem de erro substancial de $33 \%$, que a empresa gera proventos de qualquer natureza, não responderam de forma correta a pergunta, conforme Tabela 3.

Outro questionamento se refere à competência dos tributos do Imposto de Renda (IR) e do Imposto sobre Produtos Industrializados (IPI).

Tabela 4 - Competência tributária do Imposto de Renda e do Imposto sobre Produtos Industrializados O Imposto de Renda (IR) e o Imposto sobre Produtos Industrializados Quantidade $\%$ (IPI) são exemplos de tributos:

\begin{tabular}{lccc}
\hline a) Estaduais & 02 & $7 \%$ \\
\hline b) Internacionais & 0 & $0 \%$ & $93 \%$ \\
\hline c) Federais & 26 & $0 \%$ & $0 \%$ \\
\hline d) Municipais & 0 & 0 & $\mathbf{1 0 0 \%}$ \\
\hline e) Não sei & $\mathbf{2 8}$ & \\
\hline Total & & $0 \%$ \\
\hline
\end{tabular}

Fonte: dados da pesquisa

Esta foi a questão que obteve o maior índice de acerto, 93\% dos entrevistados marcaram a resposta correta, conforme Tabela 4.

A partir dessa outra questão, exigia-se um pouco de atenção além de conhecimento do aluno. Não bastava o aluno saber que o fato gerador do ISS é a prestação de serviços de qualquer natureza, o aluno deveria saber também que dentre as exceções à regra, a prestação de serviços de telecomunicação é o fato gerador do ICMS.

Tabela 5 - Cobrança ISSqn

\begin{tabular}{lcc}
\hline O ISSqn será cobrado na empresa que: & Quantidade & $\%$ \\
\hline a) preste apenas serviços de telecomunicações & 05 & $18 \%$ \\
\hline b) comercialize apenas bichos de estimação & 0 & $0 \%$ \\
\hline c) preste apenas serviços médicos & 13 & $48 \%$ \\
\hline d) trabalhe somente na transformação de produtos industrializados & 05 & $19 \%$ \\
\hline e) Não sei & 05 & $15 \%$ \\
Total & $\mathbf{2 8}$ & $\mathbf{1 0 0 \%}$ \\
\hline
\end{tabular}

Fonte: dados da pesquisa 
Por este motivo, muitos alunos acreditaram que em uma empresa de prestação de serviços de telecomunicações incidiria a ocorrência do ISS (18\% dos respondentes),também acreditaram que trabalhar somente na transformação de produtos industrializados $(19 \%$ dos respondentes) e outros preferiram não opinar (15\% dos respondentes). Somente $48 \%$ dos integrantes da amostra responderam de forma correta, demonstrado na Tabela 5.

Nesta outra questão, informou-se que no de ano de 2011, o governo autorizou empresas com faturamento anual de até R \$ 3.600.000,00 a optarem pelo SIMPLES - opção simplificada para pagamento do Imposto de Renda. Anteriormente este teto era de R\$ 2.400.000,00. (Art. $7^{\circ}$ da Lei Complementar $n^{\circ} 139$ de 2011).

Tabela 6 - Opções de tributação do Imposto de Renda

\begin{tabular}{|c|c|c|}
\hline $\begin{array}{l}\text { A empresa com faturamento anual abaixo de } \mathrm{R} \$ \mathbf{4 8 . 0 0 0 . 0 0 0 , 0 0} \text { e superior à } \\
\mathrm{R} \$ \text { 3.600.000,00, desde que não impedida por lei, poderá optar pelas } \\
\text { seguintes modalidades: }\end{array}$ & Quantidade & $\%$ \\
\hline a) Lucro Real e Presumido & 19 & $68 \%$ \\
\hline b) Simples ou Lucro Comercial & 03 & $11 \%$ \\
\hline c) Lucro Presumido ou Lucro Operacional & 0 & $0 \%$ \\
\hline d) Lucro Arbitrado e Simples & 02 & $7 \%$ \\
\hline e) Não sei & 04 & $14 \%$ \\
\hline Total & 28 & $100 \%$ \\
\hline
\end{tabular}

Fonte: dados da pesquisa

Com base nisto, os resultados evidenciaram que $68 \%$ dos alunos conseguiram responder de forma correta e 14\%, na dúvida, preferiram não opinar, conforme Tabela 6.

As três últimas perguntas envolviam os alunos com questões voltadas ao planejamento tributário. O estudante deveria ser capaz de saber o que é elisão, evasão e elusão fiscais.

Tabela 7 - Elisão

\begin{tabular}{lcc}
\hline Um sinônimo de elisão fiscal: & Quantidade & \% \\
\hline a) a sonegação de imposto por meio lícito & 04 & $14 \%$ \\
\hline b) redução da carga tributária sem burlar a lei & 12 & $43 \%$ \\
c) Lucro Presumido e Lucro Operacional & 01 & $4 \%$ \\
d) Lucro Arbitrado e Simples & 0 & $0 \%$ \\
e) Não sei & 11 & $39 \%$ \\
Total & $\mathbf{2 8}$ & $\mathbf{1 0 0 \%}$ \\
\hline
\end{tabular}

Fonte: dados da pesquisa

Desse modo, uma questão questionava o que o aluno entendia como elisão, sendo que $43 \%$ dos alunos conseguiram responder de forma correta e $39 \%$ afirmavam não saber tal 
conceito e $14 \%$ disseram que elisão é a sonegação de imposto por meio lícito, como demonstrado na Tabela 7. Presume-se que os alunos não estão totalmente familiarizados com o assunto. Algo que poderia ser muito utilizado pelos alunos que se dizem interessados, uma vez que a elisão é considerada uma prática de direito do contribuinte.

Tabela 8 - Evasão

\begin{tabular}{lcc}
\hline Constitui um ato de evasão fiscal: & Quantidade & $\%$ \\
\hline a) pagar imposto fora do prazo & 02 & $7 \%$ \\
\hline b) seguir a lei e pagar o imposto em dia & 02 & $7 \%$ \\
\hline c) burlar a lei alterando o fato gerador do tributo & 19 & $68 \%$ \\
\hline e) Não sei & 05 & $18 \%$ \\
Total & $\mathbf{2 8}$ & $\mathbf{1 0 0 \%}$ \\
\hline
\end{tabular}

Fonte: dados da pesquisa

$\mathrm{Na}$ questão sobre evasão fiscal, foi verificado que os alunos possuem mais conhecimento do que não devem fazer evasão, do que eles podem fazer, elisão. Dos respondentes, $68 \%$ dos alunos acertaram a questão e $18 \%$ do total da amostra não souberam conceituar o que é evasão, como é demonstrado na Tabela 8.

Tabela 9 - Elusão

\begin{tabular}{lrr}
\hline Você já ouviu falar no termo elusão tributária? & Quantidade & $\mathbf{\%}$ \\
\hline a) Sim & 02 & $7 \%$ \\
\hline e) Não & 26 & $93 \%$ \\
\hline Total & $\mathbf{2 8}$ & $\mathbf{1 0 0 \%}$ \\
\hline
\end{tabular}

Fonte: dados da pesquisa

$\mathrm{Na}$ questão de elusão fiscal, identificou-se que $93 \%$ dos alunos não tinham conhecimento algum sobre o termo elusão tributária, conforme exposto na Tabela 9. Deste modo, verificou-se que este é um tema que merece um maior debate nas instituições.

Com estas questões, conclui-se pela pesquisa, que o aluno necessita de mais conhecimentos sobre os assuntos tributários. Seus conhecimentos realmente não são suficientes para que estes atuem no mercado de trabalho. Uma vez que a maioria destes alunos se diz interessado, cabe a estes, procurar mais à legislação tributária e à doutrina para aprofundar e melhorar seus conhecimentos no assunto, haja vista sua complexidade e constante alteração. Um aprofundamento nesta área pode gerar um melhor respaldo legal para tomar decisões, ampliação da capacidade de interpretação relativa a impostos, melhor condição de se questionar sem receios a fiscalização, maior oportunidade de atuação no mercado e maior possibilidade de ingresso em cargos públicos. 


\section{CONSIDERAÇÕES FINAIS}

A falta de conhecimento dos estudantes de graduação em ciências contábeis sobre assuntos tributários e a confusão que fazem sobre a contabilidade e a legislação tributária são uma realidade crescente do ensino superior.

Para demostrar a importância da disciplina de contabilidade tributária atribuída por estudantes dos cursos de ciências contábeis de uma IES de Tangará da Serra - MT verificouse pelos resultados da pesquisa, que os alunos acreditam que o conhecimento contábil tributário é fornecido de forma suficiente na IES. O conteúdo programático e as matérias que abordam o tema tributário não são tão eficazes para garantir-lhes uma vaga no mercado de trabalho, aumentando assim a necessidade de maior aprofundamento da disciplina, no conteúdo aplicado pela Universidade. Satisfeitos com o conteúdo recebido, os alunos não se sentem desmotivados com a matéria e se dizem interessados por aprendê-la, tendo como motivador principal vincular teoria à prática. Desta Forma, conclui-se que os alunos pesquisados possuem bastante interesse pelo assunto. Contudo, esta área não é a mais importante para seu futuro como contabilista, pois com $54 \%$ das respostas dos acadêmicos tem enfoque somente em concursos.

Dos objetivos específicos, identificou-se a importância do conteúdo da disciplina de contabilidade tributária no curso de Ciências Contábeis, onde $64 \%$ dos acadêmicos, responderam estarem satisfeitos com o conhecimento fiscal e tributário, $71 \%$ acham que o conteúdo programático adquiridos na IES também foram suficientes e $68 \%$ dos respondentes acreditam não estarem preparados para atuar no mercado de trabalho, conforme resultados obtidos nos gráficos 1,2 e 3 .

Sugere-se como continuação a esta pesquisa, uma nova visita à IES da amostra e desta vez analisar a importância do assunto na visão dos coordenadores dos cursos e professores que aplicam a matéria, saber se estes se sentem satisfeitos com a recepção da matéria pelos alunos e quais os fatores motivacionais na aplicação da matéria, bem como analisar a questão salarial e as condições do ambiente escolar como fatores primordiais para satisfação no trabalho.

Outro ponto que pode ser pesquisado é a maneira pelas quais os contabilistas que na área tributária adquiriram seus conhecimentos no assunto. A prática pode aumentar o interesse pelo assunto ou diminuir e se os conhecimentos adquiridos por estes é resultado da 
prática ou da teoria universitária. Seria interessante a realização de pesquisas que discutam a adequação dos cursos de Ciências Contábeis frente às necessidades do mercado de trabalho.

Esta pesquisa deveria ter sido realizada em todas as instituições de ensino superior de Tangará da Serra - MT, que tinham a disciplina de Contabilidade Tributária em sua grade curricular. Somente duas instituições se enquadraram no perfil da pesquisa. Por motivo não divulgado de uma IES realizou-se o estudo somente na Universidade do Estado de Mato Grosso (UNEMAT).

\section{REFERÊNCIAS}

AGOSTINI, C.; CARVALHO, J. T. A Evolução da Contabilidade: Seus Avanços no Brasil e a Harmonização com as Normas Internacionais. Instituto de Ensino Superior Tancredo de Almeida Neves. Armário de Produção. Ano 1. N.1, Out. 2012. Disponível em:

$<$ http://www.iptan.edu.br/publicacoes/anuario_prodcientifica/arquivos/revista1/artigos/Artigo Carla_Joziane.pdf $\geq$.Acesso em: 01/05/2014.

AMED, F. J.; NEGREIROS, P. J. L.C. História dos Tributos no Brasil. São Paulo: SINAFRESP, 2009.

ARAÚJO, A. M. P.; ASSAF, A. Introdução à Contabilidade. $1^{\text {a }}$ ed. São Paulo: Atlas, 2004.

ARAÚJO, T. S; BARBOSA, R. S.; ÁVILA, L. A. C. Análise Comparativa da Percepção dos Alunos Ingressantes e Concluintes emCiências Contábeis sobre Conhecimento de Contabilidade Tributária. 2012. Disponível em:

<http://www.aedb.br/seget/artigos12/31416892.pdf>. Acesso em 30/10/2013.

Código Tributário Nacional. Disponível em:

<http:www.receita.fazenda.gov.br/Legislacao/CodTributNaci/ctn.htm>.Acesso em:

03/12/2013.

Conselho Federal de Contabilidade. Disponível em:

<http://www.cfc.org.br/uparq/decretolei_9295_1946.pdf>. Acesso em 01/05//2014.

Conselho Nacional de Educação. Resolução CNE/CES 10, de16 de Dezembro de 2004. Disponível em:

<http://portal.mec.gov.br/cne/arquivos/pdf/rces10_04.pdf>. Acesso em: 22/10/2013.

Constituição Federal/1988. Disponível em:

<http://www.planalto.gov.br/ccivil_03/constituicao/constituicao.htm>.Acesso: 07/12/2013.

CREPALDI, S. A. Curso Básico de Contabilidade, resumo da teoria, atendendo ás novas demandas da gestão empresarial. $2^{a}$ ed. São Paulo: Atlas, 1999.

FABRETTI, L. C. Contabilidade Tributária. 9ª ed. São Paulo: Atlas, 2005. 
FABRETTI, L. C. Contabilidade Tributária. 10ª ed. São Paulo: Atlas, 2006.

FARIA, M. A.; NOGUEIRA, V. Perfil do Profissional Contábil: Relações entre Formação e Atuação no Mercado de Trabalho. Perspectiva Contemporânea, v. 2, n.1, jan./jan.2007. Disponível em:

<http://www.revista.grupointegrado.br/perspectivascontemporaneas/v...php?>. Acesso em: 29/04/2014.

FILHO, J. P. F. Metodologia do Trabalho Científico: da teoria à prática. Tangará da Serra: Sanches, 2013.

HESKETH, J. L. Comportamento organizacional. Rio de Janeiro: Livros Técnicos e Científicos, 1981.

IUDÍCIBUS, S. de. Teoria da Contabilidade. 6ª ed. São Paulo: Atlas, 2000.

IUDÍCIBUS, S. Teoria da Contabilidade. 7ª ed. São Paulo: Atlas, 2004.

IUDÍCIBUS, S. Teoria da Contabilidade. 9ª ed. São Paulo: Atlas, 2009.

IUDÍCIBUS, S. de, MARION, J. C. e FARIA, A. C. Introdução à Teoria da Contabilidade. $5^{\text {a }}$ ed. São Paulo: Atlas, 2007.

INDÍCIBUS, S. de; MARTINS, E.; CARVALHO, L. N. Contabilidade: Aspectos Relevantes da Época de sua Evolução. Revista de Contabilidade e Finanças da FEA/USP. São Paulo, n 38. p. 7-19, mai./ago. 2005. Disponível em:

<http://www.fea.usp.br/conteudo.php?i=355 2 . Acesso em: 29/04/2014.

MACHADO, H. B. Curso de Direito Tributário. 29ª ed. São Paulo: Malheiros, 2008.

MARION, J. C.; ROBLES JR.A busca da qualidade no ensino superior de contabilidade no Brasil: Revista Conselho Regional de Contabilidade. São Paulo, ano 1, n.5 p. 38-45 julho, 1998.

MENDES, P. C. M.; SILVA, A. B.; NIYAMA J. K. A Aderência do Conteúdo da Disciplina Contabilidade Tributária Ministrada nos Cursos De Graduação em Ciências Contábeis do Brasil ao Conteúdo do Currículo Internacional Proposto pela ONU. Revista Ambiente Contábil, v. 3. n. 1, p. 1 - 19, jan./jun. 2011. Disponível em:

$<$ http://repositorio.unb.br/bitstream/10482/14639/1/ARTIGO_AderenciaConteudoDisciplina. pdf $>$. Acesso em 31/10/2013.

MOURA, I. J. L. A história da Contabilidade. Disponível em:

<http://www.classecontabil.com.br/artigos/ver/74>. Acesso em: 01/05/2014.

NAZÁRIO N. S.; MENDES P. C. M., AQUINO D. R. B. Percepção dos discentes quanto à importância do conhecimento em Contabilidade Tributária em instituições de ensino superior do Distrito Federal: um estudo empírico. Revista Universo Contábil, Blumenau, v. 4, n. 3, p. 64-81, jul./set. 2008. Disponível em: 
<http://proxy.furb.br/ojs/index.php/universocontabil/article/view/981>. Acesso em: 29/08/2013.

OLIVEIRA, G. P. de. Contabilidade Tributária. São Paulo: Saraiva, 2005.

OLIVEIRA, G. P. de. Contabilidade Tributária. $2^{\text {a }}$ ed. São Paulo: Saraiva, 2008.

OLIVEIRA, M. O.; CHIEREGATO, R.; JUNIOR, J. H.P.; GOMES, M. B. Manual de Contabilidade Tributária. 6 ${ }^{a}$ ed. São Paulo: Atlas, 2007.

PRODANOV, C. C.; FREITAS E. C. Metodologia do trabalho científico: Métodos e Técnicas da Pesquisa e do Trabalho Acadêmico. $2^{\text {a }}$ Ed. Rio Grande do Sul: Editora Feevale, 2013.

Resolução CFC N. 1.282/10. Disponível em:

$<$ https://www.google.com.br/\#q=resolu\%C3\%A7\%C3\%A3o+cfc+no+1282\%2F10+de+28+d e+maio+de+2010>. Acesso em: 12/09/2013.

Receita Federal. Disponível em:

<http://www.receita.fazenda.gov.br/Legislacao/LeisComplementares/2006/leicp123.htm>. Acesso em: 12/03/2014.

RIBAS, F.C. Variações motivacionais no ensino e aprendizagem de inglês em contexto de escola pública. 2008. 410 f. Tese (Doutorado em Estudos Linguísticos) - Instituto de Biociências, Letras e Ciências Exatas, Universidade Estadual Paulista "Júlio de Mesquita Filho", São José do Rio Preto, 2008. Disponível em:

<http://www.dominiopublico.gov.br/pesquisa/detalheobraform.do>. Acesso em: 10/03/2014.

SAMPIERI, R.H. Metodologia de pesquisa. Tradução de Fatima Conceição Murad, Melissa Kassner, Sheila Cara Dystyler Cadeira. $3^{a}$ ed. São Paulo: Mcgraw-Hill. 2006. 


\section{APÊNDICE A}

Este questionário pertence à Marli Anatália da Silva, acadêmico do curso de ciências contábeis, Campus da UNEMAT, Tangará da Serra/MT. Tem como propósito diagnosticar a percepção da importância do conhecimento da disciplina por discentes de instituições de ensino superior de tangará da serra - MT. Contudo, sua participação é de muita valia, em responder ao questionário abaixo conforme está indicado. Saiba que tem o direito de não responder a alguma pergunta, qualquer que seja o motivo. Lembramos que não existem respostas certas ou erradas, o que importa é sua opinião sincera. Suas respostas não serão tratadas de forma individual, mas somadas às de outras pessoas como você na composição do resultado final. Caso não responda ou não opine, peço que sinalize a alternativa correspondente para que possa ter certeza de que não se esqueceu de responder a alguma pergunta.

Antecipadamente agradeço sua atenção e empenho em responder às questões, contribuindo, assim, para o aprimoramento e desenvolvimento da pesquisa.

1. Satisfação quanto aos conhecimentos adquiridos:

a) Qual sua percepção quanto ao conhecimento fiscal/tributário, adquirido no curso de graduação?
( ) Mais que suficiente
( ) Suficiente
( ) Insuficiente
( ) Prefere não opinar

b) Em relação ao conteúdo programático das disciplinas que estão vinculadas à Contabilidade Tributária, são suficientes para o conhecimento acadêmico?

( )Mas que suficiente

( ) Suficiente

( ) Insuficiente

( ) Prefere não opinar

c) Os conhecimentos adquiridos nas IES são suficientes para se sentir capacitado para atuar no mercado de trabalho?
( ) Mas que suficiente
( ) Suficiente
( ) Insuficiente
( ) Prefere não opinar

2. Interesse pelo assunto tributário:

d) Qual ao seu interesse em relação ao conhecimento fiscal/tributário adquirido na faculdade para seu futuro como contabilista? 

( ) Tem muito interesse
( ) Têm interesse
( ) Quase nenhum interesse
( ) Nenhum interesse
( ) Prefere não opinar

e) O que lhe faz motivar com os assuntos tributários?

( ) Diversificação dos conhecimentos contábeis

( ) Captar os conhecimentos repassados pelo professor

( ) Vincular teoria à prática

( ) Conhecer as minúcias da lei

( ) Não tem motivação

f) Qual o principal fator que influência para não se sentir motivado com os assuntos tributários?

( ) O professor

( ) A Faculdade

( ) Outras áreas mais rentáveis

( ) Complexidade das leis

( ) Não fica desmotivado

g) Você já trabalhou na área de planejamento tributário, fora o ambiente acadêmico?

( ) Não sei ao certo o que fazer com os conhecimentos adquiridos

( ) Manterei distância de assuntos tributários

( ) Enfoque somente em concursos

( ) Farei especialização na área

\section{Grau de fixação dos conhecimentos tributários:}

Conhecimento sobre conceito de planejamento tributário.

h) Em minha opinião, planejamento tributário é:

( ) Diminuir impostos, não importa os métodos que sejam utilizados.

( ) Omitir informações irrelevantes para retardar a ocorrência da carga tributária.

( ) Prever a incidência do fato gerador do imposto e trabalhar para que ele não ocorra, ocorra da forma mãos amena ou postergar a sua ocorrência.

( ) Não sei.

Fato gerador do ICMS

j) Haverá a incidência do fato gerador do ICMS quando:

( ) A empresa gerar proventos de qualquer natureza.

( ) A empresa prestar serviços contábeis e advocatícios.

( ) A empresa sonegar informações ao fisco.

( ) Houver a circulação de mercadoria da matriz par a filial.

Competência tributária do Imposto de Renda e do Imposto sobre Produtos Industrializados.

k) O Imposto de Renda (IR) e o Imposto Sobre Produtos Industrializados (IPI) são exemplos de tributos: 

( ) Estaduais
( ) Internacionais
( ) Federais
( ) Municipais
( ) Não sei
Cobrança de ISS

l) O ISS será cobrado na empresa que:

( ) Preste apenas serviços de telecomunicações.

( ) Comercialize apenas bichos de estimação

( ) Preste apenas serviços médicos

( ) Trabalhe somente na transformação de produtos industrializados

( ) Não sei

Opções de tributação do Imposto de Renda

m) Empresa com faturamento anual abaixo e $R \$ 48.000 .000,00$ e superior à $R \$$ 2.400.000,00, desde que não impedida por lei, poderá optar pelas seguintes modalidades:
( ) Lucro Real e Lucro presumido
( ) Simples e Lucro Comercial
( ) Lucro Presumido e Lucro Operacional
( ) Lucro Arbitrado e Simples
( ) Não sei

\section{Elisão}

n) Um sinônimo para elisão fiscal é:

( ) A sonegação de imposto por meio lícito

( ) Redução da carga tributária sem burlar a lei

( ) Lucro presumido e Lucro Operacional

( ) Lucro Arbitrado e Simples

( ) Não sei

\section{Evasão}

o) Constitui um ato de Evasão Fiscal

( ) Pagar impostos fora do prazo

( ) Seguir a lei e pagar os impostos em dia

( ) Burlar a lei alterando o fato gerador do tributo

( ) Não sei

\section{Elusão}

p) Você já ouviu falar no termo elusão tributária?

( ) $\mathrm{Sim}$

( ) Não 


\section{ANEXO}

\section{Lista de chamada}

Periodo: 2013/2

Disciplina: TGAD282COT - CONTABIIDADE TRIBUTÁRIA

Curso: BACHARELADO EM CIÊNCIAS CONTÁBEIS

Unidade: TANGARÁ DA SERRA

Professor: 982961373 - MARCIO IRIS DE MORAES
Data de emissão: 1208:2013

$\begin{array}{ll}\text { Carga horária: } & 60.0 \\ \text { Turma: } & 2010 / 2-282 \\ \text { Sala: } & \\ \text { Frequéncia minima: } & 45.0 \text { horas } \\ \text { Código disciplina oferecida: } & 75696\end{array}$

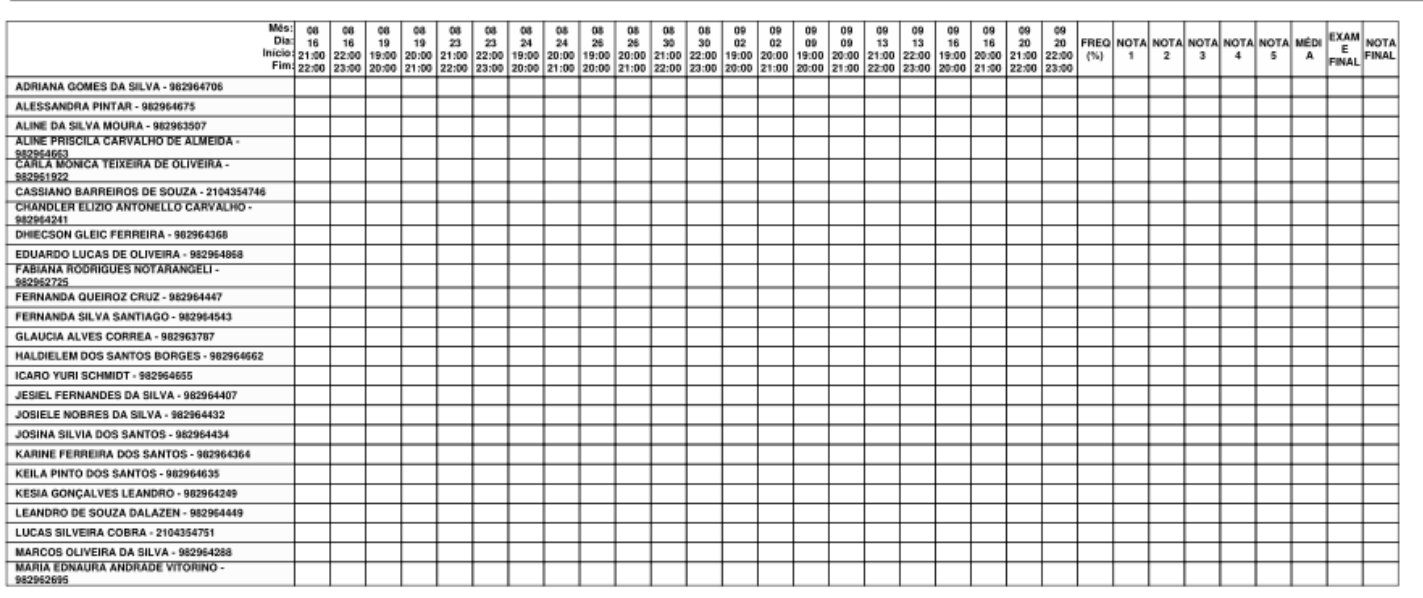

Registro de presença: Ex.: meia $=>|-1|$ inteira $|-|$

Obs.

Registro de ausência: Ex.: |

Observaçōes: " Cancelado, "“ Trancado, '“' Aproveitamento

Lista de chamada

Periodo: 2013/2

Disciplina: TGAD282COT - CONTABILIDADE TRIBUTÁBIA

Curso: BACHARELADO EM CIĖNCIAS CONTÁBEIS

Unidade: TANGARÁ DA SERRA

Professor: 982961373 - MARCIO IRIS DE MORAES
Data de emissāo: 12/08/2013

$\begin{array}{ll}\text { Carga horária: } & 60.0 \\ \text { Turma: } & 2010 / 2-282 \\ \text { Sala: } & \\ \text { Frequẻncia minima: } & 45.0 \text { horas } \\ \text { Código disciplina oferecida: } & 75696\end{array}$

\begin{tabular}{|c|c|c|c|c|c|c|c|c|c|c|c|c|c|c|c|c|c|c|c|c|c|c|c|c|c|c|c|c|c|c|c|}
\hline & 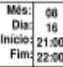 & 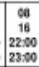 & \begin{tabular}{|c|}
6 \\
19 \\
1950 \\
20500
\end{tabular} & \begin{tabular}{|c|}
90 \\
19 \\
20,00 \\
$21 ; 00$
\end{tabular} & 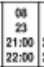 & 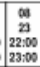 & \begin{tabular}{|c|}
20 \\
24 \\
19000 \\
$20: 00$
\end{tabular} & $\mid \begin{array}{c}0.06 \\
24 \\
2000 \\
21: 00 \\
2100\end{array}$ & 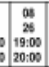 & 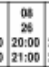 & 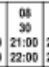 & \begin{tabular}{|c|c}
06 \\
30 \\
32.00 \\
$23: 00$ \\
23
\end{tabular} & 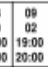 & 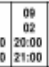 & 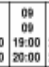 & $\begin{array}{c}09 \\
09 \\
0200 \\
21 ; 00 \\
2100\end{array}$ & \begin{tabular}{|c}
20 \\
13 \\
1300 \\
22000 \\
2200
\end{tabular} & \begin{tabular}{|c|c}
9 \\
13 \\
2200 \\
$23: 00$
\end{tabular} & 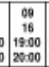 & 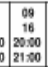 & $\mid \begin{array}{c}29 \\
20 \\
200 \\
22100 \\
2250\end{array}$ & $\left|\begin{array}{c|}690 \\
200 \\
20200 \\
23500\end{array}\right|$ & \begin{tabular}{|c|} 
FREO \\
(is)
\end{tabular} & Nota 1 & NoTA & & $\begin{array}{c}\text { NOTA } \\
4\end{array}$ & $\frac{1}{5}$ & WEOI & & $\begin{array}{l}\text { NoTAa } \\
\text { Fival }\end{array}$ \\
\hline MARLL ANATALLA DA SILVA- 962967704 & & & & & & & & & & & & & & & & & & & & & & & & & & & & & & & \\
\hline 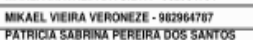 & & & & & & & & & & & & & & & & & & & & & & & & & & & & & & & \\
\hline 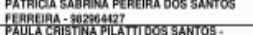 & & & & & & & & & & & & & & & & & & & & & & & & & & & & & & & \\
\hline 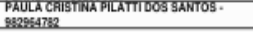 & & & & & & & & & & & & & & & & & & & & & & & & & & & & & & & \\
\hline 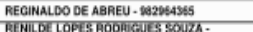 & & & & & & & & & & & & & & & & & & & & & & & & & & & & & & & \\
\hline 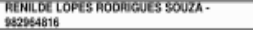 & & & & & & & & & & & & & & & & & & & & & & & & & & & & & & & \\
\hline RAXY GRACHECKI VLLAS BOAS - 9202065900 & & & & & & & & & & & & & & & & & & & & & & & & & & & & & & & \\
\hline & & & & & & & & & & & & & & & & & & & & & & & & & & & & & & & \\
\hline 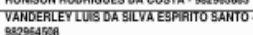 & & & & & & & & & & & & & & & & & & & & & & & & & & & & & & & \\
\hline
\end{tabular}

